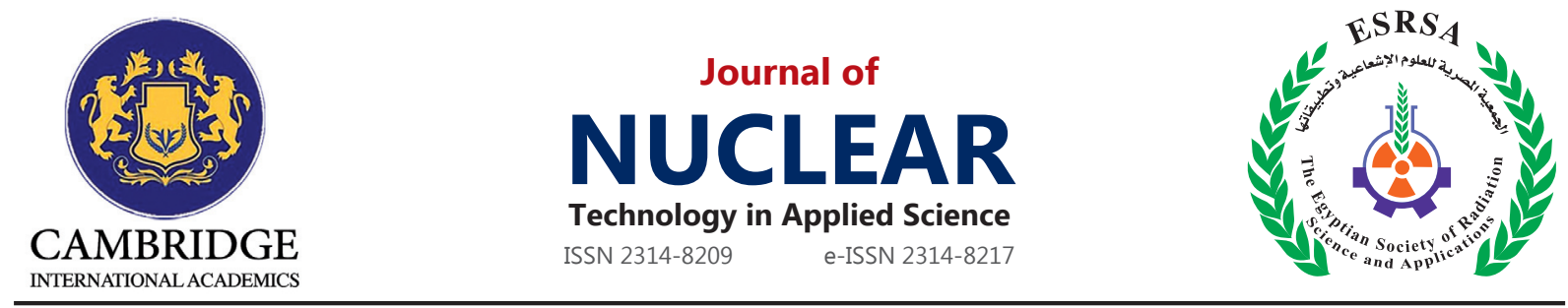

J. Nucl. Tech. Appl. Sci., Vol. 6, No. 2, PP. 83 : 91 (2018)

\title{
Thermal Hydraulic Evaluation of a proposed annular Fuel for VVER1000 Reactor
}

Hassan, A. A. and El-Sheikh, B. M.

Received: 07/05/2018

Accepted: 30/05/2018

E.mail:Hassan A.A.,azzaaea@yahoo.com

\section{KEYWORDS}

Annular Fuel,

VVER-1000, ANSYS,

Thermal Hydraulic of

Thorium Based Fuel.

\section{ABSTRACT}

Thorium based fuel is a promising fuel as it reduces the radiation protection cost of safety and improves the fuel performance with high burnup capability. In this paper the core of VVER-1000 nuclear reactor is designed with $\left(\mathrm{Th}_{0.9} \mathrm{U}_{0.1}\right) \mathrm{O}_{2}$ annular fuel rod for internally and externally cooled (dual cooled) fuel. Thermal performance of the present case is analyzed using ANSYS CFD code. Equivalent cell including a fuel rod and its surrounding coolant within a hexagonal assembly in the hot channel is simulated to get the maximum fuel temperature and maximum clad temperature. The results are compared with the calculated results obtained for the conventional $\mathrm{UO}_{2}$ fuel rod. Critical Heat Flux (CHF) and minimum DNBR are obtained and validated. The results indicated that the maximum fuel temperature of $\left(\mathrm{Th}_{0.9} \mathrm{U}_{0.1}\right) \mathrm{O}_{2}$ annular fuel is lower than that of the $\mathrm{UO}_{2}$ fuel by about $530^{\circ} \mathrm{K}$. Lower maximum temperature and flatten temperature distribution in the thorium-based annular fuel rod provides more thermal safety margin in the reactor.

1. Egyptian Nuclear and Radiological Regulatory Authority, Cairo, Egypt. 


\section{INTRODUCTION}

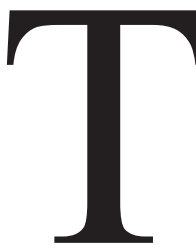

horium is a viable option for effective fuel utilization and better waste management as it is chemically stable. Regarding to the proper characteristics of the $\left(\mathrm{Th}_{0.9} \mathrm{U}_{0.1}\right) \mathrm{O}_{2}$ fuel such as higher thermal conductivity, better dimensional stability at high burnups, and lower thermal expansion coefficient than $\mathrm{UO}_{2}$ fuel, this type of fuel could be considered as the promising fuel type in the modern reactors (Chaudri et al., 2013), (Anantharaman, 2008).

All Technical parameters obtained from the previous studies on thorium fuel cycle indicate that thorium fuel cycle can be used in most reactor types already operated (UnaK, 2000).

The design of Indian Advanced Heavy Water Reactor aims to utilization of thorium on a large scale (Sinha and Kakodkar, 2006).

Finite Element (FE) method through, Computational Fluid Dynamics (CFD) simulation code are used for fuel rod thermal hydraulic calculations. Mousavizadeh et al. (2016) studied the effect of a nanofluid $\left(\mathrm{TiO}_{2} /\right.$ water $)$ on the heat transfer characteristics in VVER-1000 reactor. Zaidabadi et al. (2017) analyzed thermal hydraulic parameters and investigated the amount of thermal power uprate in a dual cooled annular fuel rod in a hot channel of VVER-1000 reactor.

This work studies the $\left(\mathrm{ThO}_{2}-10 \mathrm{w} \% \mathrm{UO}_{2}\right)$ enhanced heat transfer characteristics of dual cooled annular fuel in VVER-1000 nuclear reactor. Annular fuel is used to improve thermal efficiency of the reactor and overcome melting of the center of the fuel rod (Kazimi, 2007).

\section{THERMAL HYDRAULIC ANALYSIS OF A FUEL ROD IN THE HOT CHANNEL}

An equivalent cell that includes an annular fuel rod and its surrounding fluid in a hexagonal assem- bly of a VVER-1000 reactor, as shown in Fig.(1), is simulated where $\mathrm{R}$ is the equivalent cell radius and $\mathrm{P}$ is the pin pitch.

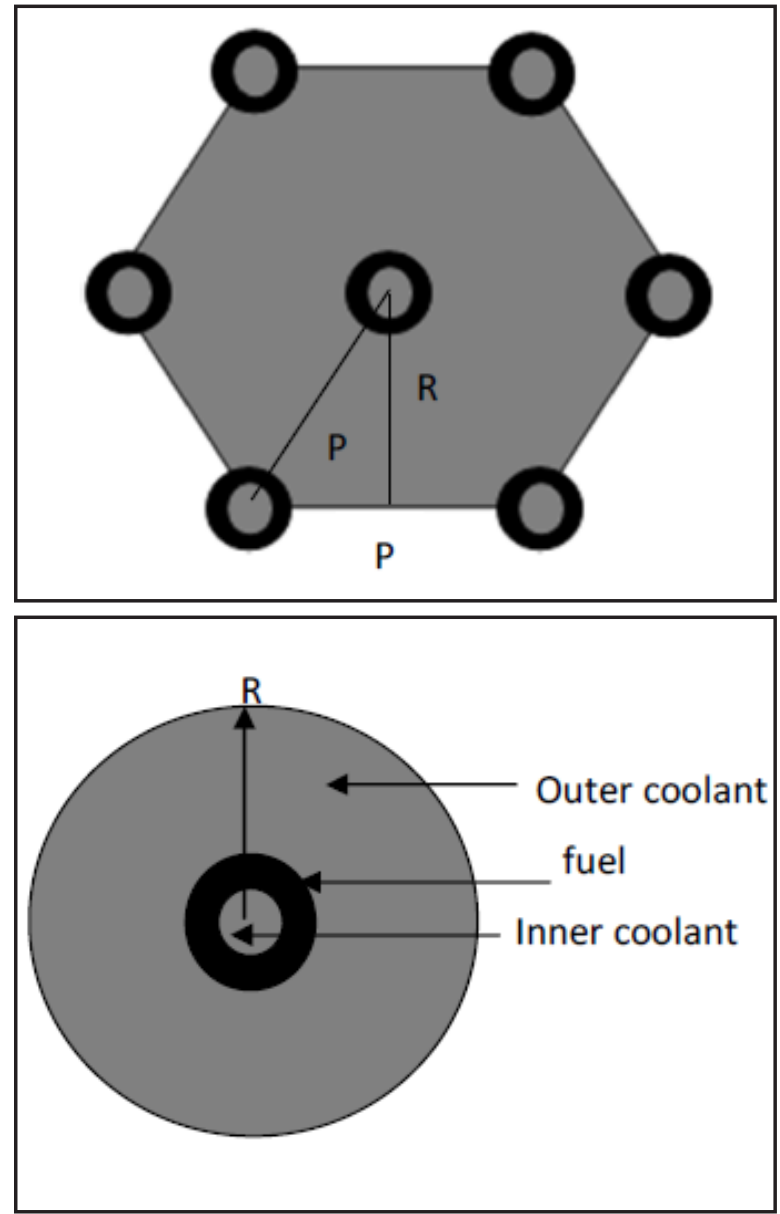

Fig. (1): The equivalent cell.

The Russian type pressurized water reactor VVER-1000 core has 163 hexagonal fuel assemblies with 311 fuel rods and a central channel per assembly. Some Characteristics of VVER 1000 reactor are provided in table 1 .

The geometrical data for the simulated internally and externally cooled annular fuel rod are presented in table 2.

The CFD package ANSYS is used for thermal hydraulic analysis. Fig. (2) represents the Finite Element (FE) equivalent cell model for the proposed dual cooled fuel. 
Table (1) : Some characteristics of VVER- 1000 reactor.

\begin{tabular}{|c|c|}
\hline Nominal heat power of the reactor $(\mathbf{M W})$ & 3000 \\
\hline Inlet coolant flow rate $\left(\mathbf{m}^{\mathbf{3}} / \mathbf{h}\right)$ & 84,800 \\
\hline Coolant temperature at the reactor inlet $\left({ }^{\circ} \mathbf{C}\right)$ & $291 \pm 2.5$ \\
\hline Fuel assembly form & Hexagonal \\
\hline Arrangement of fuel rod & Triangle \\
\hline Number of fuel assembly in the core & 163 \\
\hline Fuel rod pitch $(\mathbf{m m})$ & 12.75 \\
\hline Number of fuel rods in the FA & 311 \\
\hline Hole diameter in the fuel pellet $(\mathbf{m m})$ & 1.5 \\
\hline Fuel pellet outside diameter $(\mathbf{m m})$ & 7.57 \\
\hline Cladding outside diameter $(\mathbf{m m})$ & 9.1 \\
\hline Cladding inner diameter $(\mathbf{m m})$ & 7.73 \\
\hline Cladding material & $\mathrm{Alloy} \mathrm{Zr}+1 \% \mathrm{Nb}$ \\
\hline Fuel pellet material & $\mathrm{UO}$ \\
\hline Fuel rod effective height $(\mathbf{c m})$ & 353 \\
\hline
\end{tabular}

Table (2) : Geometrical data for the simulated dual cooled fuel rod.

\begin{tabular}{|c|c|}
\hline Fuel rod pitch $(\mathbf{m m})$ & 12.75 \\
\hline Outer clad outer diameter $(\mathbf{m m})$ & 13.66 \\
\hline Outer clad inner diameter $(\mathbf{m m})$ & 11.92 \\
\hline Fuel pellet outer diameter $(\mathbf{m m})$ & 11.82 \\
\hline Fuel pellet inner diameter $(\mathbf{m m})$ & 9.2 \\
\hline inner clad outer diameter $(\mathbf{m m})$ & 9.08 \\
\hline inner clad inner diameter $(\mathbf{m m})$ & 8 \\
\hline
\end{tabular}

Thermal hydraulic analysis was made for dual cooled annular $\left(\mathrm{Th}_{0.9} \mathrm{U}_{0.1}\right) \mathrm{O}_{2}$ fuel rod as well as the conventional $\mathrm{UO}_{2}$ fuel. All The material properties introduced to CFD code (density, thermal conductivity, specific heat capacity) are temperature dependent (IAEA- TECDOC - 1496, 2006). Sensitivity test for grid number was made for 386909, 620307, and 1125983 elements to ensure that results are independent on the number of grids resulted in selecting last model which satisfies the convergence criterion, so the maximum temperature of fuel and clad temperature are independent of the number of grids. 

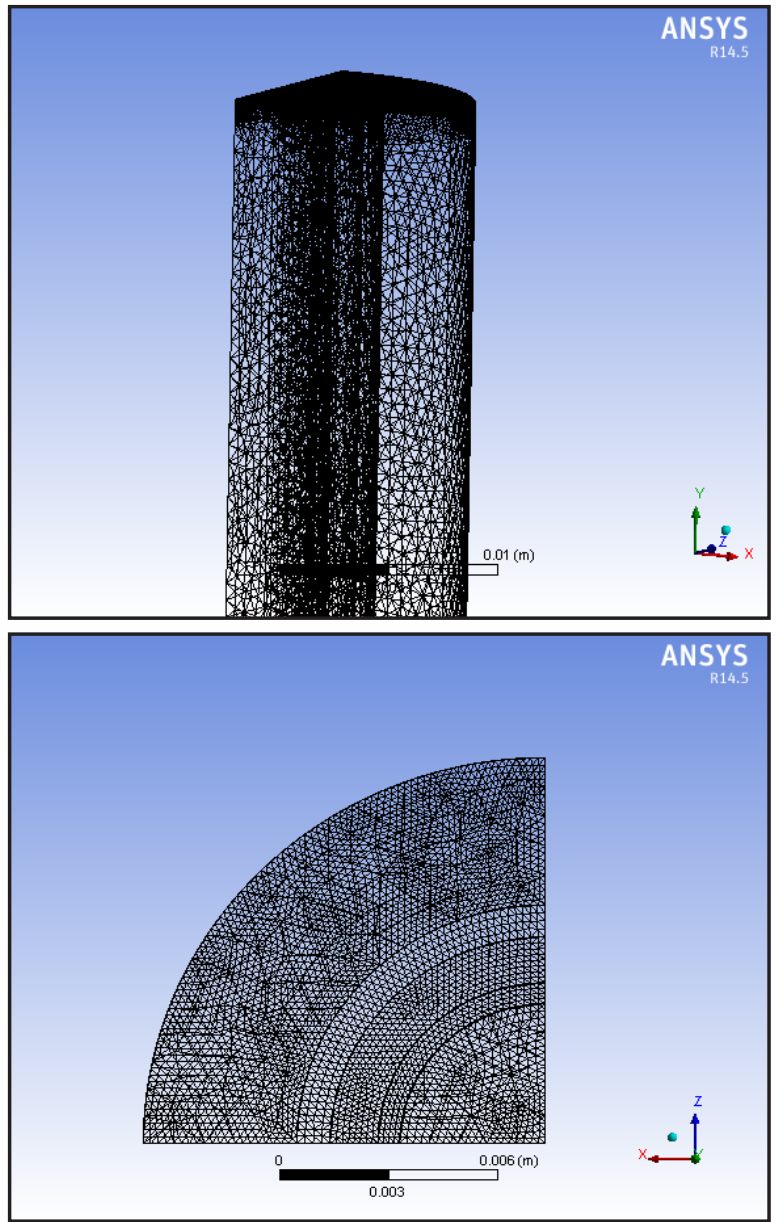

Fig. (2): The finite element equivalent cell model for the dual cooled proposed fuel.

The governing equations solved in ANSYS for flow and heat transfer considering incompressible flow are:

Conservation of mass:

$$
\nabla(\rho) \stackrel{r}{v})=0
$$

Conservation of momentum:

$$
\nabla(\rho \dot{r v})=-\nabla P+\nabla(\vec{\tau})+\rho \vec{g}
$$

The stress tensor $\tau$ is:

$$
\bar{\tau}=\mu\left(\nabla \stackrel{r}{v}+\nabla \stackrel{r}{v}^{T}\right)
$$

Where, $\rho$ is the density, $\dot{v}$ is the velocity vector, P is the pressure, $\vec{g}$ is the gravity vector and $\mu$ is the viscosity (ANSYS workbench user manual, 2007).
To calculate the maximum fuel temperature we simulate the central fuel rod in the core. The total rate at which heat is produced in the central fuel rod in MW is given by (Lamarsh and Baratt, 2001):

$$
q_{r}(0)=\frac{2.32 P E_{d}}{n E_{R}}
$$

where, $\mathrm{P}$ is the reactor power in $\mathrm{MW}, \mathrm{E}_{\mathrm{d}}$ is the energy deposited locally in the fuel per fission in joules, $n$ is the number of fuel rods in the reactor, and $E_{R}$ is the recoverable energy in fuel per fission in joules. The radial power peaking factor in that case is 2.32 .

Assuming $E_{d} / E_{R}$ is 0.95 , then $q_{r}(0)$ will be 0.13 MW.

The maximum rate of heat production occurs in the middle $(\mathrm{z}=0)$ of the central fuel rod is given by (Lamarsh and Baratta, 2001):

$q_{\max }^{\prime \prime \prime}=\frac{1.16 P E_{d}}{H a^{2} n E_{R}}$

where, $\mathrm{H}$ is the fuel rod height, and a is the fuel pellet radius.

Axial heat flux at the surface of the rod which is introduced to CFD code is given by (Lamarsh and Baratta, 2001):

$$
q^{\prime \prime}(z)=\frac{a^{2}}{2(a+b)} q^{\prime \prime \prime}(z)
$$

then,

$$
q^{\prime \prime}(z)=\frac{a^{2}}{2(a+b)} q_{\max }^{\prime \prime \prime} \cos \left(\frac{\pi z}{H}\right)
$$

Where, $\mathrm{z}$ is measured from the midpoint of the rod, and b is the clad thickness.

In the annular cylindrical element having fuel surface temperature $t_{i}$ at inner radius $r_{i}$, fuel surface temperature $t_{o}$ at outer radius $r_{o}$, and fuel thermal conductivity $k_{\mathrm{f},}$ as shown in Fig.(3). The heat generated flows out of both inner and outer surfaces; the heat flow out of the outer surface of the element, $q_{\text {so }}$ is: (Elwaki, 1971): 


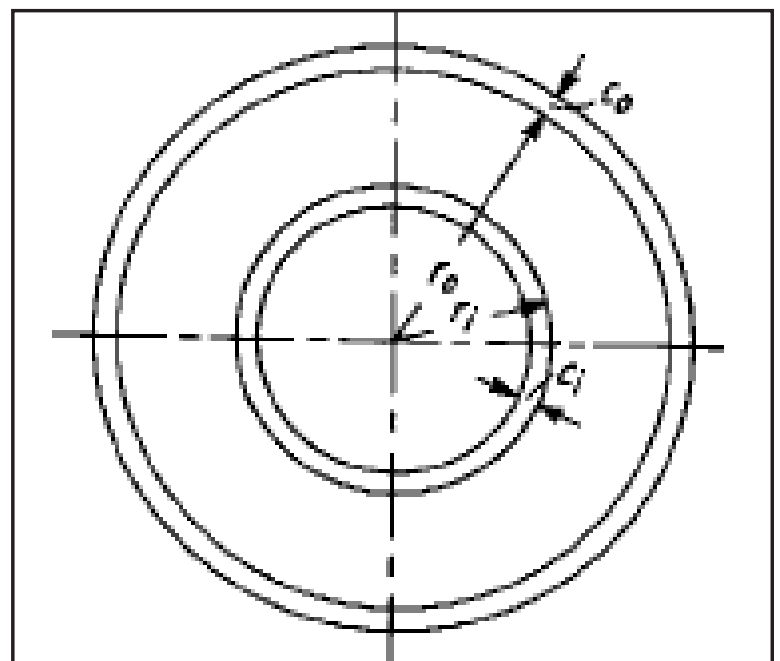

Fig. (3): Annular fuel element with inner and outer clad .

$q_{刃}=4 \pi k_{f} L\left(t_{i}-t_{o}\right) \frac{\left(\frac{r_{o}}{r_{i}}\right)^{2}-1}{\left(\frac{r_{o}}{r_{i}}\right)^{2}-2 \ln \left(\frac{r_{o}}{r_{i}}\right)-1}$

With cladding on the outer surface of thickness $\mathrm{c}_{\mathrm{o}}$ and thermal conductivity $\mathrm{k}_{\mathrm{c}}$ and coolant at $\mathrm{t}_{\mathrm{fo}}$,

$$
\begin{aligned}
& t_{i}-t_{f}=\frac{q^{\prime \prime \prime} r_{i}^{2}}{4 k_{f}}\left\lceil\left(\frac{r_{o}}{r_{i}}\right)^{2}-2 \ln \left(\frac{r_{o}}{r_{i}}\right)-1\right] \\
& +\frac{q^{\prime \prime \prime} r_{i}^{2}}{2}\left\{\left[\left(\frac{r_{o}}{r_{i}}\right)^{2}-1 \amalg \frac{1}{k_{c}} \mathrm{~h} \frac{r_{o}+c_{o}}{r_{o}}+\frac{1}{h\left(r_{o}+c_{o}\right)}\right]\right.
\end{aligned}
$$

The heat flow out of inner surfaces $\mathrm{q}_{\mathrm{si}}$ is:

$$
q_{s}=4 \pi k_{f} L\left(t_{o}-t_{i}\right) \frac{1-\left(\frac{r_{i}}{r_{o}}\right)^{2}}{\left(\frac{r_{i}}{r_{o}}\right)^{2}-2 \ln \left(\frac{r_{i}}{r_{o}}\right)-1}
$$

With cladding on the inner surface of thickness $\mathrm{c}_{\mathrm{i}}$ and coolant at $\mathrm{t}_{\mathrm{fi}}$,

$$
\begin{aligned}
& \left.t_{o}-t_{f}=\frac{q^{\prime \prime \prime} r_{o}^{2}}{4 k_{f}}\left[\frac{r_{i}}{r_{o}}\right)^{2}-2 \ln \left(\frac{r_{i}}{r_{o}}\right)-1\right] \\
& \left.+\frac{q^{\prime \prime \prime} r_{o}^{2}}{2} \llbracket 1-\left(\frac{r_{i}}{r_{o}}\right)^{2} \llbracket \frac{1}{k_{c}} \mathrm{~h} \frac{r_{i}}{r_{i}-c_{i}}+\frac{1}{h\left(r_{i}-c_{i}\right)}\right]
\end{aligned}
$$

The fluid is assumed to be single phase of incompressible liquid water, The turbulent model (k- $\varepsilon)$ is used. The gap region is neglected and the calculations are made for the centeral one meter of the fuel rod.

The boundary conditions of the simulated results are:

- The side wetted walls of the water are considered as wall boundaries.

- The fuel rod is considered fixed.

- Constant inlet mass flow rate.

- Inlet static temperature for the coolant is used.

The details of input data introduced to the CFD code are shown in table 3.

Table (3): Input data introduced to the CFD code.

\begin{tabular}{|c|c|}
\hline Mass flow rate & $1.6\left(\mathrm{~m}^{3} / \mathrm{h}\right)$ \\
\hline Inlet coolant temperature & $571(\mathrm{~K})$ \\
\hline Inlet coolant pressure & $15(\mathrm{MPa})$ \\
\hline Rod power & $0.13(\mathrm{MW})$ \\
\hline
\end{tabular}

\section{RESULTS AND DISCUSSION}

Temperature distributions of different parts of the $\left(\mathrm{Th}_{0.9} \mathrm{U}_{0.1}\right) \mathrm{O}_{2}$ annular fuel rod in working conditions are presented. The variation of outer and inner clad surface temperature along the height is shown in Fig. (4) and Fig.(5) respectively with maximum outer clad surface temperature of about $651^{\circ} \mathrm{K}$ and maximum inner clad surface temperature of about $635^{\circ} \mathrm{K}$.

Comparison of the maximum fuel temperature for $\left(\mathrm{Th}_{0.9} \mathrm{U}_{0.1}\right) \mathrm{O}_{2}$ annular fuel rod and Conventional $\mathrm{UO}_{2}$ fuel rod is presented through Fig. (6) and Fig. (7). The variation of temperature along the height on a vertical center line in the $\left(\mathrm{Th}_{0.9} \mathrm{U}_{0.1}\right) \mathrm{O}_{2}$ annular fuel rod (at $5.25 \mathrm{~mm}$ from the center) is shown in Fig. (6). The results indicated that the maximum fuel temperature at that line is about $840^{\circ} \mathrm{K}$. While The variation of temperature along the height on a vertical center line in the conventional $\mathrm{UO}_{2}$ fuel rod (at $1.517 \mathrm{~mm}$ 
from the center) is shown in Fig.(7) with a maximum fuel temperature at that line about $1370^{\circ} \mathrm{K}$.

Better thermal conductivity of $\left(\mathrm{Th}_{0.9} \mathrm{U}_{0.1}\right) \mathrm{O}_{2}$ fuel at nuclear reactor operating conditions. (6.91-4.99 $\mathrm{W} / \mathrm{m}^{\circ} \mathrm{K}$ ) in the temperature range of $873-1123^{\circ} \mathrm{K}$ ) compared with lower $\mathrm{UO}_{2}$ thermal conductivity (4.17-3.19 W/m ${ }^{\circ} \mathrm{K}$ in the temperature range of 800 $\left.-1100{ }^{\circ} \mathrm{K}\right)$ results in better fuel performance. Dual cooled annular fuel with higher mass flow rate in the annulus results in lower power peaking and flatten power distribution in the reactor core and provide more thermal safety margin.

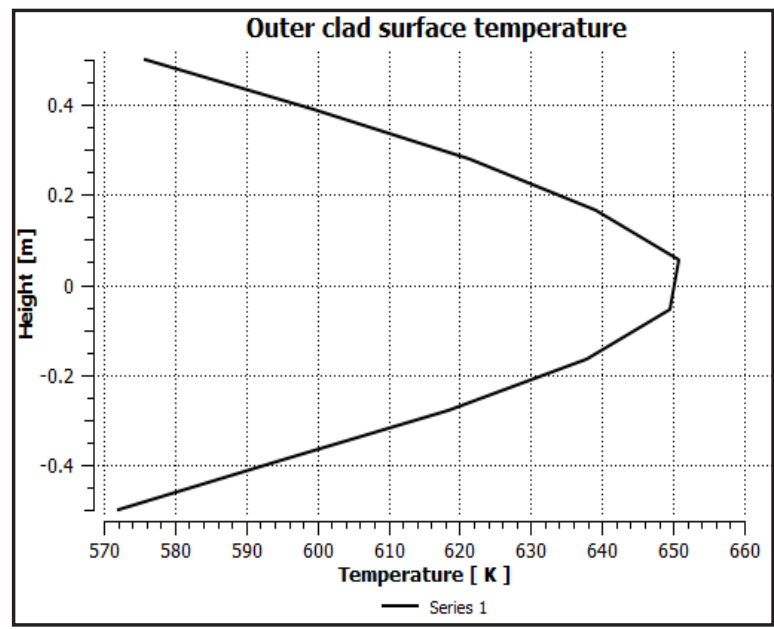

Fig. (4): $\left(\mathrm{Th}_{0.9} \mathrm{U}_{0.1}\right) \mathrm{O}_{2}$ annular fuel outer clad surface temperature along the height.

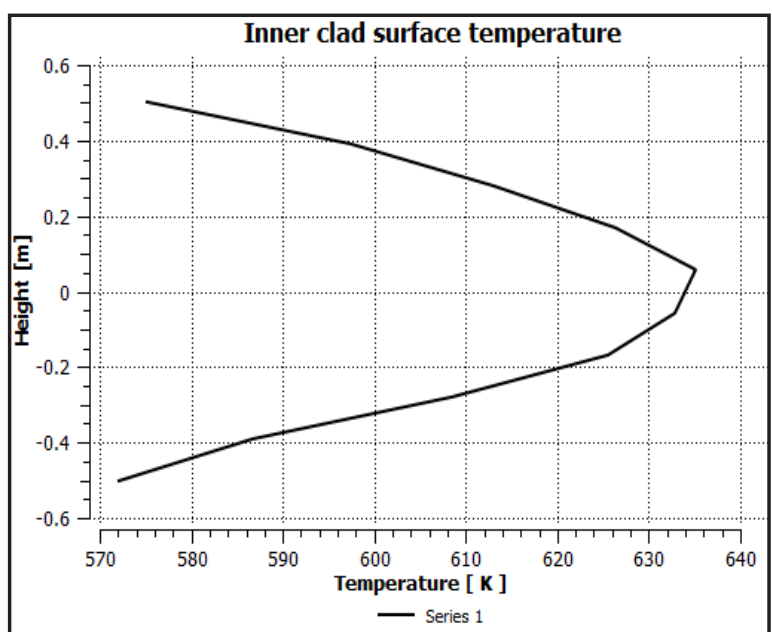

Fig. (5): $\left(\mathrm{Th}_{0.9} \mathrm{U}_{0.1}\right) \mathrm{O}_{2}$ annular fuel Inner clad surface temperature along the height.

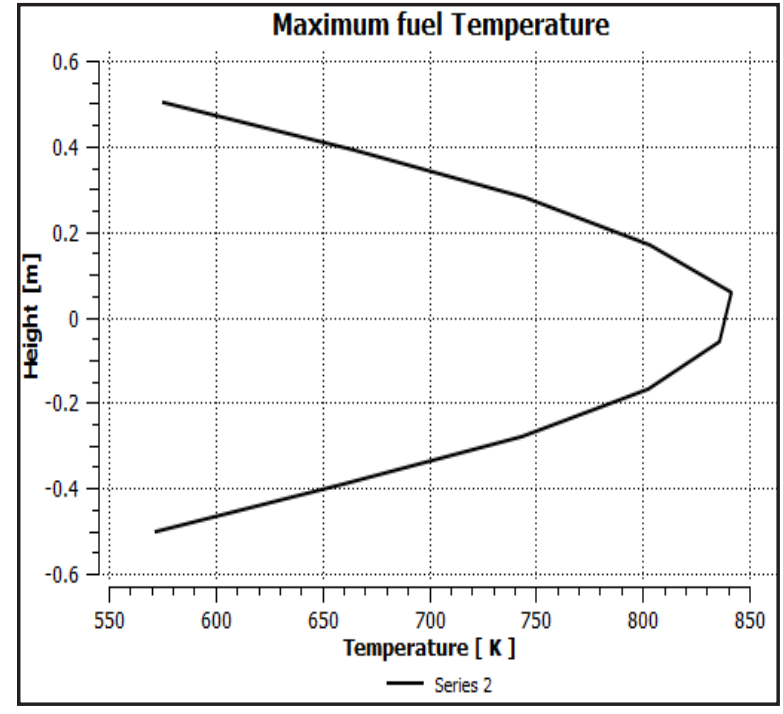

Fig. (6): $\left(\mathrm{Th}_{0.9} \mathrm{U}_{0.1}\right) \mathrm{O}_{2}$ annular fuel temperature at $5.25 \mathrm{~mm}$ axial line from the center along the height.

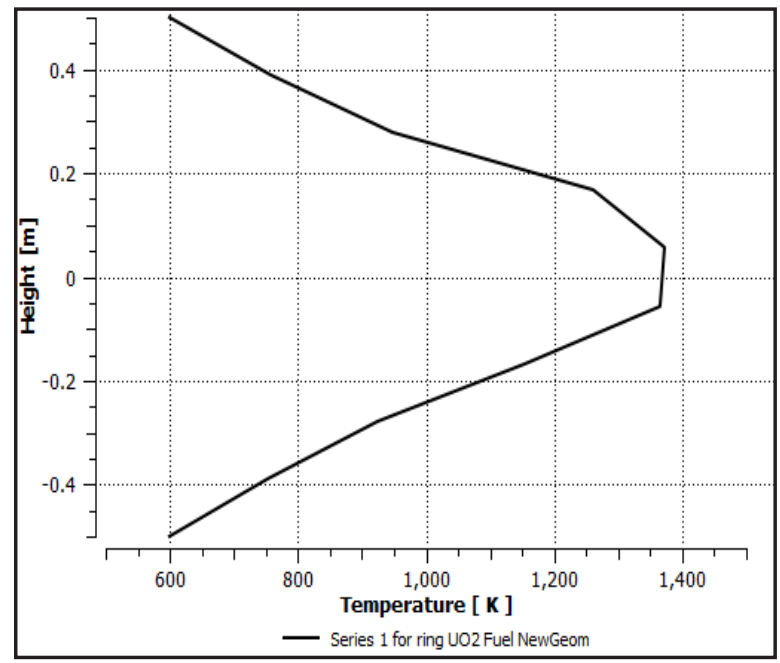

Fig. (7): Conventional $\mathrm{UO}_{2}$ Fuel temperature at $1.517 \mathrm{~mm}$ axial line from the center along the height.

The summary of the above results for the two fuel types are shown in table 4.

DNBR (Departure from nucleate boiling) is an important parameter in nuclear power reactor safety. The establishment of an allowable minimum DNBR provides a major limitation on the design of water cooled reactor (Lamarsh and Baratta, 2001). The reactor must be designed so that the heat flux q" is always below the critical heat flux (CHF) $q_{c}^{\prime \prime}$. Many correlations have been developed from data on $q_{c}^{\prime \prime}$. 
Table (4) : Maximum fuel and clad temperature for the two fuel types.

\begin{tabular}{|c|c|c|}
\hline & $\mathbf{U O}_{\mathbf{2}}$ fuel & $\left(\mathbf{T h}_{\mathbf{0 . 9}} \mathbf{U}_{\mathbf{0 . 1}}\right) \mathbf{O}_{\mathbf{2}}$ fuel \\
\hline Maximum fuel temperature $\left({ }^{\circ} \mathbf{K}\right)$ & 1370 & 840 \\
\hline Maximum outer clad temperature $\left({ }^{\circ} \mathbf{K}\right)$ & 629 & 651 \\
\hline Maximum inner clad temperature $\left({ }^{\circ} \mathbf{K}\right)$ & - & 635 \\
\hline
\end{tabular}

DNBR is calculated using the code by increasing the heat flux and determining the points at which initial boiling is occurred. Critical heat flux is obtained at these points and validated with Bernath correlation (Lamarsh and Baratta, 2001). This is a combination of the following three equations.

$$
q_{c}^{\prime \prime}=h_{c}\left(T_{w}-T_{b}\right)
$$

$T_{w c}=102.6 \ln P-\frac{97.2 P}{P+15}-0.45 v+32$

$h_{c}=10890\left(\frac{D_{e}}{D_{e}+D_{i}}\right)+\frac{48 v}{D_{e}^{0.6}}$

Where, $\mathrm{T}_{\mathrm{wc}}$ is the wall (cladding) temperature at the onset of the boiling crisis, $\mathrm{Tb}$ is the bulk temperature in Fehrenhite, $\mathrm{P}$ is the pressure in psia, $\mathrm{v}$ is the coolant velocity in $\mathrm{ft} / \mathrm{sec}, \mathrm{D}_{\mathrm{e}}$ is the equivalent diameter in feet, and $\mathrm{D}_{\mathrm{i}}$ is defined as the heated perimeter of a channel in feet divided by $\pi$. The Bernath correlation is valid for pressures between 23 and 3000 psia, fluid velocities between 4.0 and $54 \mathrm{ft} / \mathrm{sec}$, and for $\mathrm{D}_{\mathrm{e}}$ between 0.143 and 0.66 in.

The following formulas are used for DNBR calculations.

$$
D N B R=\frac{q_{c}^{\prime \prime}}{q_{a c t}^{\prime \prime}}
$$

Where $q_{c}^{\prime \prime}$ is the critical heat flux as a function of distance along the hottest coolant channel and $q_{a c t}^{\prime \prime}$ is the actual heat flux at the same position along this channel.

$$
q_{a c t}^{\prime \prime}=q^{\prime \prime \prime} * \frac{A_{f}}{C_{f}}
$$

Where, $\mathrm{q}^{\prime \prime \prime}$ is the heat production per unit volume, $\mathrm{A}_{\mathrm{f}}$ is the cross sectional area of the fuel, and $\mathrm{C}_{\mathrm{f}}$ is the circumference of the heated rod.

DNBR calculated using the code was 2.88 compared with 2.83 calculated from the Bernath correlation. Increasing the power up to MDNBR point can be achieved without occurrence of fuel melting or boiling in fluid. $\left(\mathrm{Th}_{0.9} \mathrm{U}_{0.1}\right) \mathrm{O}_{2}$ fuel provides more thermal safety margin in the reactor.

\section{CONCLUSION}

Considering the benefits of the thorium- based fuel. The core of VVER 1000 nuclear reactor is designed for $\mathrm{UO}_{2}$ as well as $\left(\mathrm{Th}_{0.9} \mathrm{U}_{0.1}\right) \mathrm{O}_{2}$ dual cooled annular fuel. An equivalent cell in the hot channel simulated using CFD code. The results indicated that the maximum fuel temperature of $\left(\mathrm{Th}_{0.9} \mathrm{U}_{0.1}\right) \mathrm{O}_{2}$ annular fuel is lower than that of the $\mathrm{UO}_{2}$ fuel by about $530^{\circ} \mathrm{K}$. Lower maximum temperature and flatten temperature distribution in the thorium-based fuel rod provide more thermal safety margin in the reactor.

\section{REFERENCES}

- Anantharaman, K.; Shivakumar V. and Saha, D. (2008): Utilization of thorium in reactors. J. Nucl. Materials, 383(1): 119.

- ANSYS workbench user manual (2007): version 11, Providence RI, USA, http://www.pdfdrive.net.

- Chaudri, K. S.; Tian, W.; Su, G. and Qiu, S. (2013): Coupled neutronics/thermal hydraulics evaluation for thorium-based fuels in thermal spectrum SCWR. Prog. Nucl. energy, 68: 55. 
- El-Wakil, M .M. (1971): Nuclear heat transport. $3^{\text {rd }}$ ed. London: International textbook company.

- IAEA- TECDOC - 1496 (2006): Thermophysical properties database of materials for light water reactors and heavy water reactors, http://www-pub.iaea. org $>$ te_1496_web.

- Kazimi, M.S. (2007): Introduction to the annular fuel special issue. Nucl. Technol., 160(1): 2.

- Lamarsh, J .R. and Baratta A. J. (2001): Introduction to Nuclear Engineering. $3^{\text {rd }}$ ed. New Gersy: Prentice Hall.

- Mousavizadeh, S.M.; Ansarifar, G.R. and Talebi, M. (2015): Assessment of the $\mathrm{TiO}_{2} /$ Water Nanofluid Effects on Heat Transfer Characteristics in VVER1000 Nuclear Ractor Using CFD Modeling. Nucl. Eng. Technol., 47: 814.
- Sinha, R.K. and Kakodkar, A. (2006): Design and development of the AHWR - the Indian thorium fuelled innovative nuclear reactor. Nucl. Eng. Des., 236: 683.

- UnaK, T. (2000): What is the potential use of Thorium in the future energy production technology. Prog. Nucl. Energy, 37: 137.

- Zaidabadi, M.; Ansarifar, G.R. and Esteki, M.H. (2017): Thermal hydraulic analysis of VVER-1000 nuclear reactor with dual-cooled annular fuel using K-E SST Turbulence model. Ann. Nucl. Energy, 101: 118 . 
التقييم الهيدروليكي الحراري لمقتوح الوقود الحلقي لمفاعل VVER 1000

إن الوقود الحلقي المزدوج هو مفهوم واعد للغايت كوقود عالي الكثافت للطاقت للهحطت

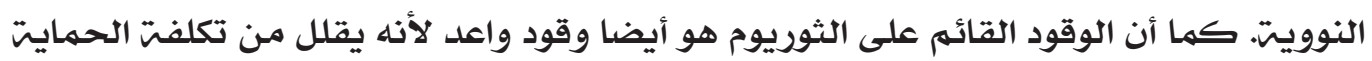
الإشعاعيت للأمان ويحسن أداء الوقود مـع قدرة عاليت للحرق. هِّ هذه الورقت تم تصميم قلب المفاعل النووي VVER 1000 بقضيب من وقود أوكسيد الثوريوم- اليورانيوم الحلقي للتبريد الداخلي والخارجي للوقود (بتبريد مزدوج ). حيث يتم

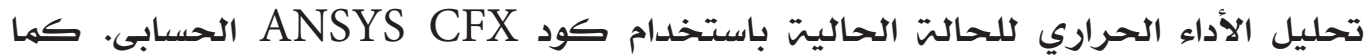

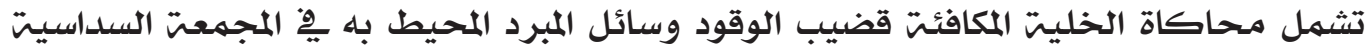

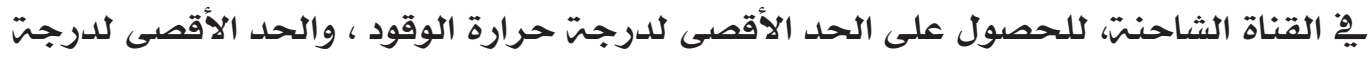
الحرارة لغلاف الوقود، والحد الأدنى لمعدل الترحيل من نواة الغليان DNBR . حيث يتم مقارنت

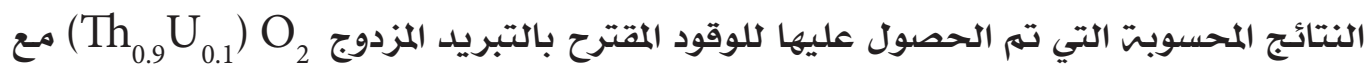
النتائج المحسوبت لقضيب الوقود UO الثائع استخدامـه. وقد أظهرت النتائج أن درجت الحرارة القصوى لقضيب الوقود الحلقى 530 درجت كلفن. درجت الحرارة القصوى الأقل وتسطيح توزيع درجت الحرارة لقضيب الوقود

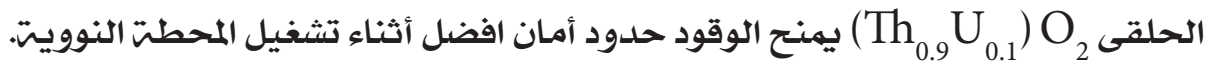


